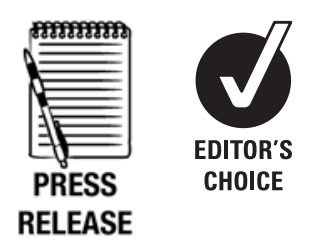

${ }^{1}$ Swansea Centre for Health Economics, College of Human and Health Sciences, Swansea University, Swansea, Wales, UK ${ }^{2}$ Division of Primary Care, University of Nottingham, Nottingham, England, UK ${ }^{3}$ Nottinghamshire County Teaching Primary Care Trust, Nottingham, England, UK ${ }^{4}$ Child Accident Prevention Trust, London, England, UK ${ }^{5}$ Public Health and Health Improvement Directorate, NHS Greater Glasgow and Clyde,

Glasgow, Scotland, UK

${ }^{6}$ School of Medicine, University of Glasgow, Glasgow, Scotland, UK

7 Faculty of Health and Social Care, University West of England, Bristol, England, UK

\section{Correspondence to}

Ceri J Phillips, School of Human and Health Sciences, Swansea University, Singleton Park, Swansea SA2 8PP, UK; c.j.phillips@swansea.ac.uk

Accepted 22 April 2011 Published Online First 13 June 2011

\title{
Preventing bath water scalds: a cost-effectiveness analysis of introducing bath thermostatic mixer valves in social housing
}

\author{
Ceri J Phillips, ${ }^{1}$ Ioan Humphreys, ${ }^{1}$ Denise Kendrick, ${ }^{2}$ Jane Stewart, ${ }^{3}$ Mike Hayes, ${ }^{4}$ \\ Lesley Nish, ${ }^{5}$ David Stone, ${ }^{6}$ Carol Coupland, ${ }^{2}$ Elizabeth Towner ${ }^{7}$
}

\begin{abstract}
Aims To assess the cost-effectiveness of installing thermostatic mixer valves (TMVs) in reducing risks of bath water scalds and estimate the costs of avoiding bath water scalds.
\end{abstract}

Methods The evaluation was undertaken from the perspective of the UK public sector, and conducted in conjunction with a randomised control trial of TMVs installed in social housing in Glasgow. Installation costs were borne by the social housing organisation, while support materials were provided by the UK NHS. Effectiveness was represented by the number of families with at-risk bath water temperatures pre- and post-installation, and the number of bath scalds avoided as a result of installation. Differences in the number of families with at-risk temperatures between groups were derived from the RCT. Cost-effectiveness was assessed and a series of one-way sensitivity analyses were conducted.

Results Unit costs associated with installation were calculated to be $£ 13.68$, while costs associated with treating bath water scalds ranged from $£ 25226$ to $£ 71$ 902. The cost of an avoided bath water scald ranged from net savings to public purse of $£ 1887$ to $£ 75520$ and at baseline produced a net saving of $£ 3229008$; that is, £1.41 saved for every £1 spent.

Conclusion It is very likely that installing TMVs as standard in social housing in new buildings and major refurbishments accompanied by educational information represents value for money.

Trial registration number ISRCTN:21179067.

\section{INTRODUCTION}

In April 2010 changes to the Building Regulations for England and Wales came into force, requiring that 'the hot water supply to any fixed bath must incorporate measures to ensure that the temperature of the water that can be delivered to the bath does not exceed $48^{\circ} \mathrm{C}^{\prime}$ in new build houses and those where there is a change of use of the building. ${ }^{1}$ Thermostatic mixer valves (TMVs) are one engineering solution to this problem, but their cost-effectiveness in domestic settings has not been evaluated.

Scald injuries place a considerable burden on health services with the individual lifetime cost for treating a severe scald estimated to be as high as $£ 250000^{2}$ and total annual health service costs in England and Wales to be over $£ 61$ million. ${ }^{3}$ Over 2600 bath water scalds occur each year in the UK. ${ }^{4}$
Young children are at particular risk; more than 400 children under 5 years of age are admitted to hospital each year, and most hospital ${ }^{4}$ and paediatric burns centre admissions ${ }^{5}$ for bath water scalds occur in this age group, as do the most severe scalds. ${ }^{4}$ Social inequalities also exist, with admission rates for burns and scalds being over three times higher among children from disadvantaged areas compared with those from affluent areas. ${ }^{6}$

Most bath hot water scalds occur from children falling or climbing unsupervised into baths, or turning on hot taps, or parents putting children into water that is too hot. ${ }^{7} 7$ In the UK, home water heater thermostats are frequently set at $60^{\circ} \mathrm{C}$ or above..$^{8}$ At this temperature adults can suffer partial or full thickness burns after 3 and 5 seconds, respectively, with burns occurring in even shorter time periods in children. ${ }^{29}$ For these reasons, a bath hot water temperature no higher than $46^{\circ}-48^{\circ} \mathrm{C}$ is recommended. ${ }^{12}$

Interventions to reduce scalds, such as tap water temperature testing and/or thermostat reduction do reduce water temperatures, but temperatures often remain above current recommended levels. ${ }^{10-14}$ Legislation to reduce thermostat settings has been more successful, with uncontrolled studies finding reductions in hospital admission rates, total body area burnt, the proportion needing skin grafts, and the proportion scarred. ${ }^{15}$ In general, it has been advocated that a combination of education and legislation is a more effective approach to prevention. ${ }^{16}$

The economic literature in this area is sparse. Legislation to lower thermostat settings on domestic hot water heaters plus annual delivery of educational information to utility company customers has been estimated to generate cost savings of \$C531 per scald averted, ${ }^{17}$ but it has not been possible to find any published economic evaluations of TMVs in a domestic setting. This study therefore aims to assess the cost-effectiveness of installing $\mathrm{TMVs}$ and providing educational materials to families living in social housing, and to estimate the cost of avoiding a bath water scald as a result of adopting the strategy.

\section{DESIGN AND METHODS}

The economic evaluation was undertaken from a UK public sector perspective and conducted alongside a randomised controlled trial (RCT) of TMVs. ${ }^{18}$ The trial was conducted in Scotland, where building regulations require TMVs to be installed in new build properties and major 
Table 1 Costs associated with the installation of thermostatic mixer valves (TMVs)

\begin{tabular}{|c|c|c|c|}
\hline Item & Unit cost $(£)$ & Source of information & Notes \\
\hline \multicolumn{4}{|l|}{ Installation; costs incurred by Housing Association } \\
\hline Cost of valve: $£ 45$ & $£ 5.41$ & Housing Association documents & $\begin{array}{l}\text { Annualised capital charges calculated using } 3.5 \% \text { annual } \\
\text { discount rate (assuming TMVs need replacing every } 10 \text { years) }\end{array}$ \\
\hline $\begin{array}{l}\text { Cost of installation: simple fit requiring removal } \\
\text { of bath panel, based on } 2 \mathrm{~h} \text { of plumber's time, } \\
\text { as at } 2008 \text { prices }\end{array}$ & $£ 103.02$ & $\begin{array}{l}\text { City buildings (Glasgow) Limited } \\
\text { Liability Partnership }\end{array}$ & Bath panel only removed to fit TMV \\
\hline $\begin{array}{l}\text { Cost of installation: complex fit requiring removal } \\
\text { of bath, based on } 4 \mathrm{~h} \text { of plumber's time, as } \\
\text { at } 2008 \text { prices }\end{array}$ & $£ 260.28$ & $\begin{array}{l}\text { City buildings (Glasgow) } \\
\text { Limited Liability Partnership }\end{array}$ & Bath needed to be disconnected to fit TMV \\
\hline Cost of repair & $£ 6.96$ & $\begin{array}{l}\text { City buildings (Glasgow) } \\
\text { Limited Liability Partnership }\end{array}$ & Assuming $11 \%$ require repair (findings from RCT) \\
\hline \multicolumn{4}{|l|}{ Educational materials; cost incurred by NHS } \\
\hline Cost of hanger & $£ 1.21$ & Personal communication & \\
\hline Cost of leaflet & $£ 0.10$ & Personal communication & \\
\hline
\end{tabular}

refurbishments. Participants comprised families with children under 5 years of age living in accommodation provided by the Glasgow Housing Association, the largest social housing provider in Europe. The costs of purchasing, fitting, replacing, and repairing TMVs were borne by the Housing Association, while educational materials were provided by the NHS. Data relating to the cost of TMVs, their installation and repair were obtained from the Glasgow Housing Association and from the City Building (Glasgow) Limited Liability Partnership, who installed the TMVs. Data relating to the educational materials were obtained from NHS staff responsible for study implementation. Estimated costs of treatment and care following a bath scald were obtained from an impact assessment for amending Part G of the Buildings Regulations 2000. ${ }^{3}$ A sensitivity analysis was carried out using cost estimates based on the findings of the Hot Water Burns Like Fire (HWBLF) campaign response to the Part G Building Regulations consultation headed by Labour MP Mary Creagh. ${ }^{19}$

Participants were randomised to a treatment arm; those in the intervention arm were offered:

- An educational leaflet mailed prior to TMV fitting.

- A TMV set at a maximum temperature of $45^{\circ} \mathrm{C}$ fitted by a qualified plumber from City Building (Glasgow) Limited Liability Partnership.

- A waterproof educational guide on how to use the TMV attached to the tap by the plumber at installation.

Control arm families were offered the intervention after collection of follow-up data. The effectiveness indicators for use in the cost-effectiveness analysis were the number of families with at-risk bath water temperatures (defined as $>46^{\circ} \mathrm{C}$ ) before installation and at follow-up, and the number of bath scalds avoided as a result of installation of the TMVs. The difference in the number of families with at-risk bath water temperature in the installation group relative to the control group was obtained from the results of the trial, while the number of bath scalds likely to be avoided following installation of TMVs was estimated from the baseline risk of a severe bath scald, adjusted for the difference in risk reduction between intervention and control arms in the RCT.

Based on estimated numbers of UK emergency department (ED) attendances from the Royal Society for the Prevention of Accidents (RoSPA) (2002 HASS/LASS figures and personal communication with RoSPA), ${ }^{20}$ and the number of hospital admissions reported by the Department of Trade and Industry (DTI) in 1999, ${ }^{4}$ it has been assumed that approximately 1107 children aged $0-4$ years attend an ED each year with bath water scald injuries. ${ }^{20}$ Of these, 249 require specialist treatment or hospitalisation of at least 5 days, and 188 are inpatients for less than 5 days $^{4}$; therefore 670 attend EDs but are not admitted to hospital (classed here as minor injuries). Additionally, DTI data ${ }^{4}$ report that an estimated 2.3 children aged $0-4$ years die each year from bath scalds. However, fatalities are not included in the analysis or costing detailed in this paper.

There are an estimated 3496200 children aged $0-4$ years in the UK. ${ }^{21}$ The target group for this analysis is children in this age group living in social housing. However, there are no published figures for the number of 0 -4-year-olds in social housing in the UK. Therefore, we have used the percentage of children living in low income households $(30 \%),{ }^{22}$ which equates to 1048860 children, and divided this by the average number of dependent children per family in UK households $(1.8)^{23}$ to derive the number of 'at-risk' households of 582700.

Further, given that not every child who attends the ED with a bath scald lives in social housing, the level of risk was based on published rates for hospital admissions for thermal injuries in children in England, by quintiles of the Townsend deprivation score.

Table 2 Estimated NHS costs by severity and calculation of unit cost of NHS treatment

\begin{tabular}{llllr}
\hline $\begin{array}{l}\text { Severity of injury from } \\
\text { impact assessment } \\
\text { (2005-10 unit costs) }^{\mathbf{3}}\end{array}$ & $\begin{array}{l}\text { Equivalent from } \\
\text { DTI report }\end{array}$ & $\begin{array}{l}\text { Cost per } \\
\text { person }\end{array}$ & $\begin{array}{l}\text { No. of 0-4-year- } \\
\text { olds affected } \\
\text { per year }\end{array}$ & $\begin{array}{l}\text { Total cost by } \\
\text { age/severity }\end{array}$ \\
\hline $\begin{array}{l}\text { Very serious with } \\
\text { intensive care }\end{array}$ & $\begin{array}{l}\text { Severe injuries }(\geq 5 \text { days as inpatients } \\
\text { and/or transfer to specialist burns unit) }\end{array}$ & $£ 80516$ & 147 & $£ 11835852$ \\
$\begin{array}{l}\text { Serious } \\
\text { Minor injuries }\end{array}$ & $\begin{array}{l}\text { Severe injuries }(<5 \text { days as inpatients) } \\
\text { Attend emergency department, but } \\
\text { discharged and do not require admission }\end{array}$ & $£ 41134$ & 111 & $£ 4565874$ \\
& & & $\begin{array}{l}\text { Average NHS } \\
\text { treatment cost }\end{array}$ & $£ 71100$ \\
& & & & $£ 25226$ \\
\hline
\end{tabular}


Table 3 Estimates of number of emergency department (ED) attendances and hospital admissions from 2002 HASS/LASS ${ }^{20}$ and DTI (1999) ${ }^{4}$

\begin{tabular}{llll}
\hline 0-4 years & $\begin{array}{l}\text { Estimated } \\
\text { number } \\
\text { per year }\end{array}$ & $\begin{array}{l}\text { Estimated number of } \\
\text { children living in social } \\
\text { housing scalded each year }\end{array}$ & Source of information \\
\hline $\begin{array}{l}\text { Severe injuries ( } \geq 5 \text { days as } \\
\text { inpatients and/or transfer } \\
\text { to specialist burns unit) }\end{array}$ & 249 & 147 & HASS/LASS (2002) and DTI (1999) \\
$\begin{array}{l}\text { Severe injuries }(<5 \text { days as } \\
\text { inpatients) }\end{array}$ & 188 & 111 & HASS/LASS (2002) and DTI (1999) \\
$\begin{array}{l}\text { Minor injuries (attend ED, } \\
\text { but discharged and do not } \\
\text { require admission) }\end{array}$ & 670 & 395 & HASS/LASS (2002) and DTI (1999) \\
\begin{tabular}{l} 
Total injuries (ED + inpatient) \\
\hline
\end{tabular} & 1107 & 653 & HASS/LASS (2002) \\
\hline
\end{tabular}

These showed that admission rates per 10000 children over the period 1992-97 were zero in the two most affluent quintiles, 4.9 in the middle quintile, and 16.0 and 29.9 in the two most deprived quintiles, respectively. ${ }^{6}$ Based on this, we estimated that approximately $59 \%$ of children admitted to hospital with thermal injuries would reside in the most disadvantaged areas, and assumed that these children would live in social housing. Therefore the estimated numbers of children aged $0-4$ years in this target risk group having a bath water scald and attending an ED would be 653; the number of children aged $0-4$ years requiring hospitalisation for $\geq 5$ days or treatment at a specialist burns centre would be 147; the number of children aged $0-4$ years requiring shorter period of hospitalisation would be 111; and the number of children aged $0-4$ years requiring an ED attendance, but who were not admitted to hospital, would be 395 .

A series of one-way sensitivity analyses tested the robustness of the findings to variations in underlying assumptions. Key parameters used in assessing the relative cost-effectiveness-rate of risk reduction, number of children aged $0-4$ years suffering bath water scalds, percentage of children with very serious bath water scalds requiring treatment at a specialist burns centre or prolonged hospitalisation-were all adjusted by $\pm 30 \%$.

\section{RESULTS}

\section{Determination of the costs of installing TMVs}

The costs of purchasing, fitting, replacing, and repairing TMVs are shown in table 1, categorised according to which agency paid for the specific component of the service.

Costs to the NHS were obtained from the Department for Communities and Local Government Impact Assessment of amending Part G of the Building Regulations. ${ }^{3}$ These costs were derived from NHS data gathered between 2005 and 2009, categorised by injury severity. The reported unit costs of NHS treatment for children aged $0-14$ years are $£ 80516$ for very serious cases ( $£ 72246$ if no intensive care unit care provided),
$£ 41134$ for serious cases, and $£ 180$ for minor injuries. ${ }^{3}$ The average treatment cost, as shown in table 2, would therefore amount to $£ 25226$.

Lifetime societal costs (including OALY losses, loss of human output, and further medical treatment) were not included in the impact assessment or in the baseline costeffectiveness calculation, but were considered within the sensitivity analysis using data from the HWBLF campaign's response to the Part G Building Regulations consultation, ${ }^{19}$ which estimated the wider societal treatment costs for a bath scald (using the incidence figures above) of $£ 71902$.

\section{Reduction of risk of bath water scalds}

The baseline risk of a bath water scald was based on estimates that approximately 653 children aged $0-4$ years attend EDs each year with scald injuries, 147 require specialist treatment or hospitalisation of at least 5 days, 111 are inpatients for less than 5 days, and 395 attend an ED and do not require admission (table 3).

As described above, the estimated number of 'at-risk' social housing households in the UK was 582 700. The risk of a child in this target risk group having a bath water scald was estimated as 1 in 892 (653/582 700); the risk of a child requiring hospitalisation for $\geq 5$ days or treatment at a specialist burns centre was estimated as 1 in 3964 (147/582 700); the risk of a child aged 0-4 years requiring a shorter period of hospitalisation was estimated as 1 in 5250 (111/582 700); and the risk of a child aged $0-4$ years requiring an $\mathrm{ED}$ attendance was estimated as 1 in 1475 (395/ $582700)$ (table 4).

The percentage of families in the intervention arm pre-TMV installation with bath water temperature considered to be at-risk (ie, $>46^{\circ} \mathrm{C}$ ) was $100 \%$; this reduced to $19 \%$ at follow-up, a reduction in risk of 0.81 . The percentage of families in the control arm with bath water temperature considered to be at-risk (ie, $>46^{\circ} \mathrm{C}$ ) was $100 \%$ at baseline and $87 \%$ at follow-up, a reduction in risk of $0.13 .{ }^{18}$ The difference in scald risk reduction between groups was therefore $0.68(0.81-0.13)$ (table 5).

Table 4 Risk of scalds based on 2002 HASS/LASS ${ }^{20}$ and DTI (1999) ${ }^{4}$

\begin{tabular}{lllll}
\hline $\begin{array}{l}\text { Severity of } \\
\text { injury }\end{array}$ & $\begin{array}{l}\text { Estimated } \\
\text { number } \\
\text { per year }\end{array}$ & $\begin{array}{l}\text { Estimated number of } \\
\text { affected households in } \\
\text { social housing in the UK }\end{array}$ & $\begin{array}{l}\text { Risk within } \\
\text { population }\end{array}$ & $\begin{array}{l}\text { \% Risk within } \\
\text { population }\end{array}$ \\
\hline $\begin{array}{l}\text { Severe injuries ( } \geq 5 \text { days as inpatients } \\
\text { and/or transfer to specialist burns unit) }\end{array}$ & 147 & 582700 & 1 in 3964 & $0.025 \%$ \\
$\begin{array}{l}\text { Severe injuries ( }<5 \text { days as inpatients) } \\
\begin{array}{l}\text { Minor injuries (attend emergency } \\
\text { department, but discharged } \\
\text { and do not require admission) }\end{array}\end{array}$ & 111 & 582700 & 1 in 5250 & $0.019 \%$ \\
\begin{tabular}{l} 
Total injuries \\
\hline
\end{tabular} & 695 & 582700 & 1 in 1475 & $0.068 \%$ \\
\hline
\end{tabular}


Table 5 Thermostatic mixer valve pre- and post-installation risk

\begin{tabular}{|c|c|c|}
\hline & $\begin{array}{l}\% \text { Of families with } \\
\text { at-risk bath water } \\
>46^{\circ} \mathrm{C} \text { (intervention) }\end{array}$ & $\begin{array}{l}\% \text { Of families } \\
\text { with at-risk bath } \\
\text { water }>46^{\circ} \mathrm{C} \text { (control) }\end{array}$ \\
\hline Baseline & $100 \%$ & $100 \%$ \\
\hline Follow-up & $19 \%$ & $87 \%$ \\
\hline Reduction in risk & $81 \%$ & $13 \%$ \\
\hline $\begin{array}{l}\% \text { Risk difference } \\
\text { between groups }\end{array}$ & $\begin{array}{l}68 \% \text { reduction } \\
(0.81-0.13)\end{array}$ & \\
\hline
\end{tabular}

A $68 \%$ reduction in scald risk would reduce the risk of children aged $0-4$ years requiring hospitalisation for $\geq 5$ days or treatment at a specialist burns centre following a bath water scald to 1 in 12398, the risk of a child aged 0-4 years requiring shorter periods of hospitalisation to 1 in 16186, and the risk of a child aged $0-4$ years requiring an ED attendance to 1 in 4625; and would reduce the risk of total ED attendances/admissions to 1 in 2788 (see table 6).

\section{Cost-effectiveness of installing TMVs}

In order to assess the relative cost-effectiveness of TMVs, the perspective employed in the baseline analysis was that of the UK public sector and was based on the assumption that the costs of TMV installation are incurred as an integral part of refurbishment or rebuild of the housing stock. The cost of the intervention to the Housing Association consisted of the cost of purchasing and repairing TMVs (based on 11\% needing repair) being $£ 12.37$, and the cost to the NHS of education materials of $£ 1.31$ - a total cost of $£ 13.68$. Therefore, based on a risk reduction of $68 \%$, estimated ED attendances and hospital admissions described above, and the total cost of installing a TMV (£13.68), the cost per percentage reduction in at-risk families is $£ 0.20$ (£13.68/0.68). The cost of averting one bath scald would result in savings to the public purse of $£ 7273$ (table 7), based on average NHS treatment costs of a scald of $£ 25226$ (table 2). If the wider societal treatment costs (incorporating lost output, OALY costs, etc) of $£ 71902$ were used from the 2008 HWBLF campaign response to Part G consultation, ${ }^{19}$ this would result in a net saving to the public purse for every scald avoided of $£ 53949$ (table 7).

\section{Impact on the public purse}

The net cost to the public purse of installing TMVs as part of new builds or major refurbishments where a new bath is installed compared to the total NHS costs of treatment per scald were estimated. First, based on average NHS costs per injured child (£25226) multiplied by the estimated number of scalds averted each year in the target group (444), the total NHS costs avoided would be $£ 11200344$ per year. The cost of installing a TMV (£13.68) in the estimated number of households in social housing (582 700) would amount to $£ 7971336$, producing a net saving of $£ 3229008$ - that is, approximately $£ 1.41$ saved for every pound spent.

The net cost to the public purse of installing TMVs as a standalone installation in existing bathrooms where a plumber removes the bath panel to fit the TMV is much higher. This includes the cost of a simple fit requiring removal of the bath panel (£103.02), the cost of the TMV (£5.41), the cost of repair (£6.96), the cost of a hanger (£1.21), and the cost of the leaflet (£0.10). Installation costs are thus $£ 116.70$, which when multiplied by the estimated number of affected households (582 700), produces a cost of $£ 68001090$. When the 'lifetime' cost of NHS treatment (£71902) is used, then the total annual cost of NHS treatment is $£ 31924488$ and a net positive cost overall of $£ 36076602$ (table 7).

\section{Sensitivity analysis}

The sensitivity analysis took into consideration the following: changes to the base-case minimum cost of installation; the percentage risk reduction from use of TMVs; number of children aged $0-4$ years having bath water scalds per annum; percentage of children aged $0-4$ years with bath water scald requiring at least 5 days hospitalisation or transfer to a specialist hospital or unit; percentage of children aged $0-4$ years with a bath water scald requiring at least 5 days hospitalisation or transfer to a specialist hospital or unit (based on wider societal treatment costs of $£ 71902$ ); estimated number of affected households in social housing in the UK; maximum cost of purchasing and installation of TMVs and educational materials from a wider societal perspective; changes in the base-case minimum cost of installation and treatment costs with wider societal treatment costs of $£ 71902$; and finally, the estimated number of children admitted to hospital with thermal injuries residing in the most disadvantaged areas (59\%). Each of these parameters in the assessment of relative cost-effectiveness was adjusted by $\pm 30 \%$ and the results are shown in table 8 . The cost of the intervention of $£ 13.68$ has been used as the base-case for the purpose of the sensitivity analysis.

Sensitivity analyses indicated that the cost of purchasing and installing the TMV and the cost of treating a scald requiring five or more days hospitalisation or transfer to a specialist burns hospital or unit had the greatest impact on the cost per scald averted.

\section{DISCUSSION}

\section{Principal findings}

This economic analysis has demonstrated that the installation of TMVs in social housing with children under the age of 5 years, when undertaken as part of new build or major

Table 6 Reduction in child risk post-thermostatic mixer valve (TMV) installation (based on TMVs reducing risk by $68 \%$ ) (HASS/LASS ${ }^{20}$ and DTI (1999) ${ }^{4}$ )

\begin{tabular}{|c|c|c|c|c|}
\hline $\begin{array}{l}\text { Severity of } \\
\text { injury }\end{array}$ & $\begin{array}{l}\text { Estimated number } \\
\text { per year }\end{array}$ & $\begin{array}{l}\text { Estimated number of } \\
\text { affected households in } \\
\text { social housing in the UK }\end{array}$ & $\begin{array}{l}\text { Risk within } \\
\text { population }\end{array}$ & $\begin{array}{l}\% \text { Risk within } \\
\text { population }\end{array}$ \\
\hline $\begin{array}{l}\text { Severe injuries ( } \geq 5 \text { days as inpatients } \\
\text { and/or transfer to specialist burns unit) }\end{array}$ & 47 & 582700 & 1 in12398 & $0.008 \%$ \\
\hline Severe injuries ( $<5$ days as inpatients) & 36 & 582700 & 1 in16 186 & $0.006 \%$ \\
\hline $\begin{array}{l}\text { Minor injuries (attend emergency } \\
\text { department, but discharged and do not } \\
\text { require admission) }\end{array}$ & 126 & 582700 & 1 in 4625 & $0.022 \%$ \\
\hline Total injuries & 209 & 582700 & 1 in 2788 & $0.036 \%$ \\
\hline
\end{tabular}


Table 7 Estimated cost of averting one bath water scald

\begin{tabular}{lll}
\hline & $\begin{array}{l}\text { NHS } \\
\text { perspective }\end{array}$ & $\begin{array}{l}\text { Lifetime } \\
\text { perspective }\end{array}$ \\
\hline $\begin{array}{l}\text { Estimated total number of scalds per year } \\
\text { Estimated number of affected households }\end{array}$ & 653 & 653 \\
in social housing in the UK & 582700 & 582700 \\
$\begin{array}{l}\text { Protected children (due to 68\% reduction } \\
\text { in risk) }\end{array}$ & 444 & 444 \\
Average NHS costs per injured child & $£ 25226$ & $£ 71902$ \\
Cost of TMV & $£ 13.68$ & $£ 13.68$ \\
Total cost of TMV installation & $£ 7971336$ & $£ 7971336$ \\
NHS costs avoided & $£ 11200344$ & $£ 31924488$ \\
Net savings of programme & $£ 3229008$ & $£ 23953152$ \\
Net saving per scald avoided & $£ 7273$ & $£ 53949$ \\
& & \\
Cost of TMV & $£ 13.68$ & $£ 116.70$ \\
Total cost of TMV installation & $£ 7971336$ & $£ 68001090$ \\
NHS costs avoided & $£ 11200344$ & $£ 31924488$ \\
Net savings (costs) of programme & $£ 3229008$ & $(£ 36076602$ ) \\
Net benefit (cost) per $£ 1$ spent & $£ 1.41$ & $(£ 0.47)$ \\
\hline
\end{tabular}

TMV, thermostatic mixer valve.

refurbishment with installation of a new bath, is likely to produce cost savings for the public purse. This finding was robust to adjusting all parameters used in the analyses by a factor of $\pm 30 \%$, except when the risk reduction is lowered to 0.48 , the estimated number of children scalded reduces to 457 , or when TMVs are fitted as a stand-alone installation in existing bathrooms. These parameters then produce positive costs (table 8).

\section{Strengths and limitations of the study}

To our knowledge this is the first economic evaluation of TMVs in a domestic setting. Our finding of a $68 \%$ reduction in water temperatures to the recommended 'safe' level of $68 \%$ is larger than the reduction in admission rates (57\%) found in an uncontrolled study evaluating a programme of interventions to reduce scalds in families in high-risk areas, including installing anti-scald devices in showers, sinks, or baths depending on parent preference. ${ }^{24}$ Were we to base our analyses on a reduction in scald risk of $57 \%$, the cost of averting one bath scald would result in savings to the public purse of $£ 3798$, based on average NHS treatment costs of a scald of $£ 25226$. If the wider societal treatment costs of $£ 71902$ were used, this would result in a net saving to the public purse for every scald avoided of $£ 50474$.

It is generally accepted that interventions resulting in a cost per OALY of less than $£ 20000-£ 30000$ represent value for money. ${ }^{25}$ A cost-utility analysis of a specialised burn treatment centre in Spain estimated a mean EQ-5D score at follow-up of $0.87 .^{26}$ The study did not report a pre-injury EQ-5D score, but assuming a utility decrement of 0.13 (consistent with the findings from a recent study of hospitalised adults with burns ${ }^{27}$ ) which applies over the remaining lifetime, a bath water scald would result in a loss of 9.1 OALYs (70 additional life years $\times$ 0.13 loss of quality of life) on average over a lifetime, and a loss of 3.5 OALYs if discounted at $3.5 \%$ per annum. In order for TMVs to be within the cost-effectiveness threshold for value for money, the cost per scald averted would have to be $<£ 105000$ (ie, $£ 30000 \times 3.5$ QALYs). If the assumption regarding the utility decrement for childhood bath water scalds is a reasonable one, our findings suggest that fitting TMVs in social housing during new builds or major refurbishments falls within the threshold defined as 'value for money'.

Our findings are likely to be generalisable to families living in social housing in the UK and other countries with similar costs of purchasing and installing TMVs and healthcare costs. They are not generalisable to families who do not live in social housing, whose risk of scalds would be lower. Furthermore, in this situation, families would need to fund the purchase and fitting of TMVs, while the NHS would benefit from savings from averted scalds. This highlights an important issue, relating to who pays for the safety intervention and who receives the benefits. In this study the costs were mainly incurred by the housing association, with the benefits we included in our base-case analysis accruing to the NHS. However, public health interventions such as these are likely to have benefits beyond the health sector and the analysis demonstrated that cost savings were larger when a wider societal perspective was employed.

Table 8 One-way sensitivity analysis

\begin{tabular}{|c|c|c|c|}
\hline Parameter & Base-case & Range of values & Cost per scald avoided \\
\hline $\begin{array}{l}\text { Base-case minimum cost of installation incurred by Housing } \\
\text { Association and costs of education materials incurred by } \\
\text { NHS (£13.68) (£) }\end{array}$ & $£ 13.68$ & $£ 9.58-17.78$ & Cost savings of $£ 12653$; cost savings of $£ 1892$ \\
\hline $\begin{array}{l}\text { Number of children aged } 0-4 \text { years having bath water } \\
\text { scalds per annum }\end{array}$ & 653 & $457-849$ & $£ 405$; cost savings of $£ 11411$ \\
\hline $\begin{array}{l}\text { Percentage of children } 0-4 \text { years with bath water scald } \\
\text { requiring } \geq 5 \text { days hospitalisation or transfer to specialist } \\
\text { hospital or unit }\end{array}$ & $23 \%$ & $16-30 \%$ & $\begin{array}{l}\text { Cost savings of } £ 4680 \text { (based on treatment costs decreasing } \\
\text { to } £ 22633 \text { ); cost savings of } £ 10229 \text { (based on treatment } \\
\text { costs increasing to } £ 28182 \text { ) }\end{array}$ \\
\hline $\begin{array}{l}\text { Percentage of children } 0-4 \text { years with bath water scald } \\
\text { requiring } \geq 5 \text { days hospitalisation or transfer to specialist hospital } \\
\text { or unit (based on wider societal treatment costs of } £ 71902 \text { ) }\end{array}$ & $23 \%$ & $16-30 \%$ & $\begin{array}{l}\text { Cost savings of } £ 53949 \text { (based on treatment costs } \\
\text { remaining at } £ 71902 \text { as per HWBLF response) }\end{array}$ \\
\hline Estimated number of affected households in social housing in the UK & 582700 & $407890-757510$ & Cost savings of $£ 12659$; cost savings of $£ 1887$ \\
\hline $\begin{array}{l}\text { Maximum cost of purchasing and installation } \\
\text { of TMVs and educational materials }\end{array}$ & $£ 273.96$ & $£ 191.77-356.15$ & $£ 226451-442181$ \\
\hline $\begin{array}{l}\text { Base-case minimum cost of installation incurred by Housing } \\
\text { Association and costs of education materials incurred by } \\
\text { NHS }(£ 13.68)(£) \text { with treatment costs based on wider societal } \\
\text { treatment costs of } £ 71902\end{array}$ & $£ 71902$ & $£ 50331-93473$ & Cost savings of $£ 32378$; cost savings of $£ 75520$ \\
\hline Estimate for admitted patients only & $297 / 437$ & & Cost savings of $£ 1614-45062$ \\
\hline
\end{tabular}




\section{Comparisons with existing literature}

We have not been able to find any published economic evaluations of installing TMVs with which to compare our estimates. The 2004 Cochrane Review by Turner et al ${ }^{28}$ does highlight studies that report drops in scald incidence, however they draw attention to methodological issues that weaken the results of several of these studies. And most, if not all of the studies tend to be designed around literature dissemination and none of the RCTs actually used a TMV and/or direct action against water temperature. Therefore, we have no comparative proportional reduction estimates to use in this paper. A recent cost-effectiveness analysis of legislation to set thermostats on new domestic water heaters to a maximum $49^{\circ} \mathrm{C}$ and annual educational information sent to utility company customers found the intervention resulted in a saving of \$C531 per scald averted. ${ }^{17}$ This intervention was much cheaper than installing TMVs, and as the legislation applied to the entire population, not just those living in social housing, the potential impact may be greater. However, findings from our RCT indicated that most families would not be happy with kitchen hot water at the same temperature as their bath hot water. ${ }^{18}$ This suggests that similar legislation to lower new boiler thermostats may not be acceptable to the UK population.

\section{Implications for policy and research}

It is very likely that installing TMVs in social housing new builds and major refurbishments with installation of new baths accompanied by educational information represents value for money (as measured by cost/OALY). Current building regulations for England and Wales mandate TMVs in new builds and where there is a change of use of the building, but do not mandate TMVs when bathroom fittings (eg, a bath) are merely replaced. Disadvantaged families who are less likely to live in new build accommodation are therefore likely to benefit less from current regulations than more affluent families, potentially increasing inequalities in scalds. Social housing providers should therefore consider fitting TMVs when baths are replaced, as well as complying with existing building regulations.

Further work is required to estimate the long-term cost of bath water scalds to children, families, and society, and to quantify their impact on quality of life. The impact of amendments to the building regulations for England and Wales requires evaluation, especially in terms of their effect on inequalities in childhood bath water scalds.

Acknowledgements Thanks are extended to Elizabeth Orton.

Funding National Institute for Health Research, Accidental Injury Prevention Research Initiative (001/0009). The final study design, data collection, analysis, interpretation of results, and paper writing was the sole responsibility of the authors. The views and opinions expressed in this paper do not necessarily reflect those of the funding body. This is an independent report commissioned and funded by the Policy Research Program in the Department of Health. The views expressed are not necessarily those of the Department.

\section{Competing interests None.}

Patient consent Obtained.

Ethics approval The trial protocol was reviewed by Nottingham Research Ethics Committee. As the trial did not involve NHS staff or patients and hence did not fall within the remit for NHS ethics committee approval, the committee was able to provide a review, but not approval. The trial received NHS organisational approval from Nottinghamshire County Primary Care Trust (PCT) (formerly Broxtowe and Hucknall PCT) as some research staff working on the trial were employed by the PCT.

Provenance and peer review Not commissioned; externally peer reviewed.

\section{REFERENCES}

1. http://www.thenbs.com/BuildingRegs/KnowledgeCentre/ShowContents.aspx? section $=\mathrm{G} \&$;topic $=\mathrm{G} 1001 \mathrm{gTOC}=$ truegtl $=$ no (accessed 1 Nov 2010).

2. http://www.brebookshop.com/details.jsp?id=144605 (accessed 1 Nov 2010).

3. Department of Communities and Local Government. Consultation on: The Building Act 1984, The Building Regulations 2000. Impact Assessment of Amending Part G (Hygiene) of the Building Regulations and the Revision to Approved Document G. London: Communities and Local Government Publications, 2008.

4. Department of Trade and Industry. Consumer Safety Research: Burns and Scalds Accidents in the Home. London: DTI, 1999.

5. Cerovac S, Roberts AH. Burns sustained by hot bath and shower water. Burns 2000:26:251-9.

6. Hippisley-Cox J, Groom L, Kendrick D, et al. Cross sectional survey of socioeconomic variations in severity and mechanism of childhood injuries in Trent 1992-7. BMJ 2002;324:1132-4.

7. Yeoh C, Nixon JW, Dickson W, et al. Patterns of scald injuries. Arch Dis Child 1994; 71:156-8.

8. Stephen FR, Murray JP. The prevention of hot tap water burns-a study of electric immersion heater safety. Burns 1991;17:417-22.

9. Feldman KW. Help needed on hot water burns. Pediatrics 1983;71:145-6.

10. Katcher ML, Landry GL, Shapiro MM. Liquid-crystal thermometer use in pediatric office counseling about tap water burn prevention. Pediatrics 1989:83:766-71.

11. Katcher ML. Prevention of tap water scald burns: evaluation of a multi-media injury control program. Am J Public Health 1987;77:1195-7.

12. Webne S, Kaplan BJ, Shaw M. Pediatric burn prevention: an evaluation of the efficacy of a strategy to reduce tap water temperature in a population at risk for scalds. J Dev Behav Pediatr 1989;10:187-91.

13. Waller $\mathbf{A E}$, Clarke JA, Langley JD. An evaluation of a program to reduce home hot tap water temperatures. Aust J Public Health 1993;17:116-23.

14. Kendrick D, Coupland C, Mulvaney C, et al. Home safety education and provision of safety equipment for injury prevention (review). Cochrane Database Syst Rev 2007, (1):CD005014.

15. Erdmann TC, Feldman KW, Rivara FP, et al. Tap water burn prevention: the effect of legislation. Pediatrics 1991;88:572-7.

16. Fallat ME, Rengers SJ. The effect of education and safety devices on scald burn prevention. J Trauma: Injury Infection and Critical Care 1993;34:560-3.

17. Han RK, Ungar WJ, Macarthur C. Cost-effectiveness analysis of a proposed public health legislative/educational strategy to reduce tap water scald injuries in children Inj Prev 2007:13:248-53.

18. Kendrick D, Stewart J, Smith S, et al. Randomised controlled trial of thermostatic mixer valves in reducing bath hot tap water temperature in families with young children in social housing. Arch Dis Child 2011;96:232-9. [Epub ahead of print].

19. Creagh M. Hot Water Burns Like Fire-Response to Part G Consultation. London, UK: The Houses of Parliament, 2008.

20. http://www.hassandlass.org.uk/query/MainSelector.aspx (accessed 11 Oct 2010).

21. http://www.statistics.gov.uk/statbase/Product.asp?vlnk=15106 (accessed 10 Sep 2009).

22. http://www.poverty.org.uk/16/index.shtml (accessed 1 Nov 2010).

23. http://www.statistics.gov.uk/cci/nugget.asp?id=1865 (accessed 1 Nov 2010)

24. Cagle KM, Davis JW, Dominic W, et al. Results of a focused scald-prevention program. J Burn Care Res 2006;27:859-63.

25. NICE. Guide to the Methods of Technology Appraisal (Reference N0515). 2004 http://www.nice.org.uk/niceMedia/pdf/TAP_Methods.pdf laccessed 12 Oct 2009).

26. Sánchez JL, Perepérez SB, Bastida JL, et al. Cost-utility analysis applied to the treatment of burn patients in a specialized center. Arch Surg 2007; 142:50-7.

27. Oster C, Willebrand M, Dyster-Aas J, et al. Validation of the EQ-5d questionnaire in burn-injured adults. Burns 2009;35:723-32.

28. Turner C, Spinks A, McClure R, et al. Community-based interventions for the prevention of burns and scalds in children. Cochrane Database Syst Rev 2004;(3): CD004335 